\title{
Model Pembelajaran Teks Tanggapan Bahasa Indonesia yang Efektif di Jenjang SMP
}

\author{
Fivi Yulianti \\ E-mail: fivi.yulianti0585@ student.unri.ac.id \\ *Program Studi Pendidikan Bahasa dan Sastra Indonesia, Universitas Riau
}

\section{Pengantar}

Pelaksanaan proses pembelajaran di dalam kelas dialksanakan dan dipengaruhi oleh berbagai faktor dianataranya peserta didik, teanaga pendidik, dan sarana pendukung. Sehingga dalam pelkasanaannya ketercapaian tujuan pembelajaran dapat terlaksana dengan maksimal. Tenaga pendidik tentu ingin informasi dari yang disampaikan dapat dipahami peserta didik. Namun, kenyataan yang dihadapi justru berbanding terbalik dengan yang ada.

Memperhatikan fakta yang muncul, tentunya kefektifan suatu proses pembelajaran jarang sekali dapat tercaai dengan baik. Persoalan pendidikan, khususnya yang berkenaan dengan mutu atau kualitas pendidikan ini menyangkut terselenggaranya mutu proses dan hasil pendidikan. Mutu proses pendidikan dan pembelajaran ini perlu diselaraskan dengan standar proses yang ada.

Pembelajaran yang efektif biasanya ditandai dan diukur oleh tingkat ketercapaian tujuan oleh sebagian besar siswa. Tingkat ketercapain itu berarti pula menunjukkan bahwa sejumlah pengalaman belajar secara internal dapat diterima oleh para siswa. Dengan demikian, pembelajaran yang efektif itu tidak bisa dilepaskan dari pembelajaran yang berkualitas karena kualitas hasil belajar itu tergantung pada efektivitas pembelajaran yang terjadi atau diterjadikan di dalam proses pembelajaan itu sendiri.

Perlu adanya inovasi dalam pelaksanaan kegiatan pembelajaran dengan memanfaatk berbagai media baik itu media online maupun media bentuk fisik sebagai bentuk menarik kembali perhatian peserta didik. Terlebih lagi peserta didik dijenjang sekolah menengah pertama masih sangat terobsesi dengan 
kegiatan bermain. Maka perlu dirancang kegiatan belajar yang menyenangkan sehingga peserta didik bisa menerima materi secara maksimal.

Penulis membuat tulisan ini dengan merujuk pada pelaksanaan pembelajaran bahasa Indonesia di jenjang sekolah menegah pertama dengan menggunakan materi teks tanggapan. penulis bertujuan agar pelaksanaan pembelajaran daring dapat terlaksana dengan optimal sehingga peserta didik dapat menyerap ilmu dengan sebaik-baiknya.

\section{Tindakan yang Dilakukan}

Perlu adanya tindakan nyata agar pembelajaran teks tanggapan ini dapat terlaksana dengan baik. Guru yang baik mampu menyususn model pembelajaran yang sistematis sehingga tidak terjadi penyelewengan proses dari pembelajaran. Penulis menyusun sistematis tindakan menjadi tiga bagian yakni pendahuluan, inti, dan penutup.

Pendahuluan merupakan tahap mengecek kesiapan peserta didik dengan melakukan do'a bersama sebelum kelas dimulai. Setelah membaca do'a bersama guru mengecek kehadiran dan dilanjutkan dengan pengenalan materi sehingga peserta didik dapat gambaran terkait bahasan. Dari sana, muncul rasa ingin tahu dari peserta didik dan guru melemparkan pertanyaan ringan tentang teks tanggapan yang diakitkan dengan kehidupan nyata.

Selanjutnya pada proses inti pembelajaran guru menklarifikasi masalah yang muncul dari materi teks tanggapan ini. dengan memebagikan peserta didik dalam beberpa kelompok selanjutnya memberikan ilustrasi gambar terkait dengan materi teks tanggapan. Dengan ini, peserta didik mampu termotivasi untuk memecahkan masalah yang terdapat pada gambar dengan menuliskan atau bertanya permasalahan atau hal-hal yang belum dipahami.Setelah terkumpul hasil diskusi dari masing-masing kelompok yang telah dibagikan. Guru akan membantu peserta didik untuk masalah-masalah sulit yang ditemukan peserta didik untuk selanjutnya menyelesaikan masalah dengan cermat, dan teliti.

Pada bagian penutup guru memberikan refleksi berupa tugas membuat resume individu sebagai pelatihan ketrampilan dalam menyelesaikan masalah 
teks tanggapan. Guru memberikan penguatan materi dan arahan untuk mencari referensi terkait baik melalui buku, perpustakaan maupun yang tersedia diinternet.

\section{Sarana Pendukung}

Tak hanya tindakan yang diperlukan dalam pelakanaan belajar mengajar, tetapi sarana pendukung yang juga turut menjadi unsur penting dalam menciptakan suasana pembelajaran yang efektif pada mata pelajaran bahasa Indonesia. Sarana pendukung tersebut antara lain:

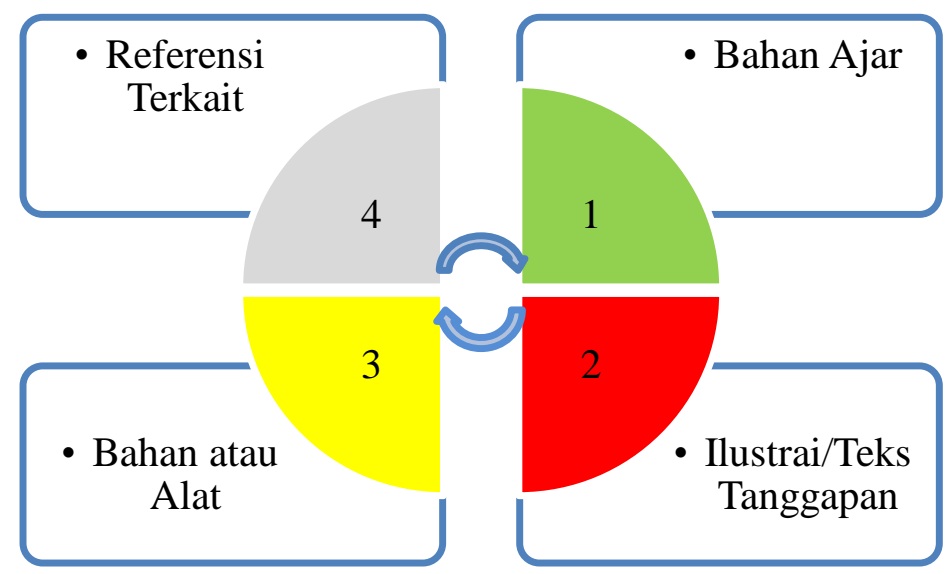

Gambar 1. Sarana Pendukung Pembelajaran Efektif.

1. Bahan ajar, sebagai seorang guru tentulah harus menyiapkan bahan ajar untuk digunakan dalam menyampaikan materi terkait. Bahan ajar ini merupakan sumber utama dari pembelajaran berupa, buku ajar dan buku latihan.

2. Ilustrasi/Teks Tanggapan disiapkan untuk bahan diskusi peserta didik dalam pemecahan masalah. Sehingga peserta didik mampu belajar secara komunikatif dengan kelompoknya. Serta dapat mengasah ketrampilan terkait materi teks tanggapan.

3. Bahan atau Alat yang digunakan dalam meunjang proses pembalajaran teks tanggapan ini ialah kertas plano, kertas metaplain, dan spidol yang digunakan sembari menjelasakn sebagai media ilustratif nyata sehingga peserta didik mampu melihat secara lansung dan menerima materi dengan baik.

4. Referensi terkait menjadi saran pendukung dalam penguatan materi kepada peserta didik. Peserta didik dapat menggunakan buku-buku ataupun mencari 
diinternet. Sehingga pembelajaran tidak dilaksanakan dikelas saja, tetapi juga diluar kelas.

\section{Tindakan Solutif}

Selain sarana pendukung, guru bahasa Indonesia harus mampu sigap dalam menghadapai kendala dalam proses pelaksanaan pembelajaran . Guru harus mampu menyiapkan solusi terhadap kemungkinan-kemungkinan yang dapat menjadi penghalang dalam proses pembelajaran.

Karena kegiatan pembelajaran ini sudah dilaksanakan semi daring. Maka tindakan solutif ialah dengan secara lansung menyerahkan tugas pengumpulan kepada guru yang bersangkutan.

\section{Simpulan}

Pembelajaran bahasa Indonesia khusunya dalam materi teks tanggapan perlu ditemukan model pembelajaran yang efektif sehingga peserta didik dapat menerima materi secara optimal. Dalam pelaksanaan pembelajaran teks tanggapan dapat dengan tindakan merancang sistematis pelaksanaan pembelajaran sehingga terarah, seperti pendahuluan dengan membuka kelas secara komunikatif, inti yakni memberikan keleluasaan peserta didik dalam memecahkan masalah, dan penutup dengan memberikan refleksi sehingga materi dapat diterima dengan baik.

Selain dibarengi tindakan juga harus mempersiapkan sarana pendukung dan penyelesaian saat menemukan kendala dalam proses pelaksanaan pembelajaran. Saran pendukung antara lain bahan ajar, ilustrasi atau teks tanggapan, bahan atau alat, dan referensi terkait dengan materi teks tanggapan. Namun, pasti akan menemukan kendala terkait sarana pendukung tersebut, karena telah dilaksanakan pembelajaran semi daring maka peserta didik dapat lansung menyerahkan tugas mereka kepada guru yang bersangkutan. 


\section{Referensi}

Bistari, B. (2017). Konsep dan indikator pembelajaran efektif. Jurnal Kajian Pembelajaran dan Keilmuan, 1(2), 13-20.

Mustafa, M. N., \& Zulhafizh, Z. (2018). Information Mastery By Teachers As A Strategy To Succeed In The Implementation Of Teaching And Learning Activities. In International Seminar and Annual Meeting BKS-PTN Wilayah Barat 2018 (pp. 516-523), Palembang.

Mustafa, M. N., \& Zulhafizh. (2017). Building the Professionalism of Teachers as an Effort to Improve Education. In Husein, R, et al (Eds.), International Seminar and Annual Meeting 2017 Fields of Linguistics, Literature, Arts, and Culture, Medan, 449.

Setyosari, P. (2017). Menciptakan pembelajaran yang efektif dan berkualitas. Jinotep (jurnal inovasi dan teknologi pembelajaran): kajian dan riset dalam teknologi pembelajaran, 1(1), 20-30. 


\section{*Data Penulis}

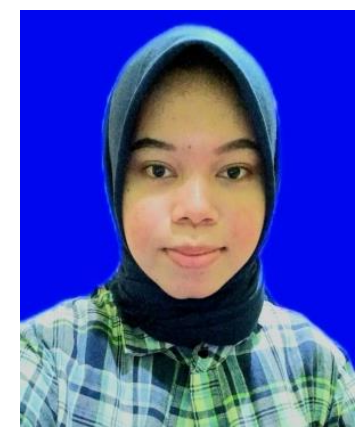

Fivi Yulianti, lahir di Dumai, 26 Juni 2002. Pada tahun akademik 2020-2021 Ia melanjutkan studi pada strata satu Jurusan Pendidikan Bahasa dan Seni di Program Studi Pendidikan Bahasa dan Sastra Indonesia FKIP Universitas Riau melalui jalur SNMPTN, dan sampai sekarang masih berstatus mahasiswa. Ia merupakan penulis cerpen dengan judul Tragedi Kecelakaan Vanesa Angel dan Bibi serta aktif diorganisasi Himaprodi PBSI sebagai anggota divisi Pemberdayaan Perempuan periode 2021-2022.

Kontak:

Hp/WA : + 6282171967261

Email : fivi.yulianti0585@student.unri.ac.id 